\title{
PENANAMAN NILAI AGAMA HINDU PADA ANAK USIA DINI DI TK PELANGI DHARMA NUSANTARA
}

\author{
Ida Bagus Putu Eka Suadnyana a
}

a Sekolah Tinggi Agama Hindu Negeri Mpu Kuturan Singaraja

a idabaguseka09@gmail.com

(Diterima: 19 Juli 2021; Direvisi: 22 Juli 2021; Diterbitkan: 26 Juli 2021)

\begin{tabular}{l}
\hline Keywords: \\
\hline Planting, Hindu \\
Religious Values, \\
Early Childhood
\end{tabular}

Kata kunci:

Penanaman

Nilai, Agama

Hindu, Anak

Usia Dini

\begin{tabular}{l} 
Abstract \\
\hline Early age is the right time to develop children's potential and \\
intelligence. To avoid developing the potential of children at \\
random, it is necessary to instill Hindu religious values from \\
an early age. Seeing the learning pattern that is contrary to \\
the provisions of the minister of education which prohibits \\
calistung in early childhood, the researchers are interested in \\
researching this at Pelangi Dharma Nusantara \\
Kindergarten. The theory used to solve the research problem \\
is the humanistic theory and the behavioristic theory. This \\
research is in the form of qualitative research. Data were \\
collected by three techniques, namely observation, interview \\
and document study. After the data is collected, the data is \\
analyzed by data reduction, data presentation, and drawing \\
conclusions. Based on the analysis, the following conclusions \\
were obtained: (1) The methods used in the activities of \\
inculcating Hindu religious values in early childhood at \\
Pelangi Dharma Nusantara Kindergarten are methods of \\
playing, habituation, field trips and exemplary, (2) Efforts \\
made by teachers in overcoming problems instilling Hindu \\
religious values in early childhood at Pelangi Dharma \\
Nusantara Kindergarten is by providing supervision, \\
understanding, introducing noble behaviorand counseling to \\
parents of students
\end{tabular}

\section{Abstrak}

Usia dini merupakan saat yang tepat dalam mengembangkan potensi dan kecerdasan anak. Untuk menghindari pengembangan potensi anak yang asalasalan, maka perlu penanaman nilai agama Hindu sejak anak usia dini. Melihat pola pembelajaran yang bertentangan dengan ketentuan menteri pendidikan 
yang melarang calistung pada anak usia dini, maka peneliti tertarik untuk meneliti hal tersebut di TK Pelangi Dharma Nusantara. Teori yang digunakan untuk memecahkan masalah penelitian ini adalah teori humanistik dan teori behavioristik. Penelitian ini berbentuk penelitian kualitatif. Data dikumpulkan dengan tiga teknik yaitu observasi, wawancara dan studi dokumen. Setelah data terkumpul, data dianalisis dengan reduksi data, penyajian data, serta penarikan kesimpulan. Berdasarkan analisis tersebut diperoleh kesimpulan sebagai berikut: (1) Metode yang digunakan dalam kegiatan penanaman nilai agama Hindu pada anak usia dini di TK Pelangi Dharma Nusantara yaitu metode bermain, pembiasaan, karya wisata dan keteladanan, (2) Upaya yang dilakukan guru dalam mengatasi problematika penanaman nilai agama Hindu pada anak usia dini di TK Pelangi Dharma Nusantara adalah dengan memberikan pengawasan, pemahaman, mengenalkan perilaku mulia dan konseling kepada orang tua siswa

\section{PENDAHULUAN}

Usia dini merupakan saat yang tepat dalam mengembangkan potensi dan kecerdasan anak. Pengembangan potensi anak secara terarah pada rentang usia tersebut akan berdampak pada kehidupan masa depannya. Sebaliknya, pengembangan potensi anak yang asal-asalan, akan berakibat pada potensi anak yang jauh dari harapan. Untuk menghindari terjadinya hal tersebut maka penanaman nilai agama Hindu perlu ditanamkan sejak anak usia dini, hal tersebut sangat penting untuk memperkuat pondasi dari dalam diri seorang anak sehingga kelak dikemudian hari mereka akan lebih dapat mengendalikan diri dan berpikir sebelum melakukan suatu tindakan.
Pada buku Upadesa disebutkan bahwa, dalam ajaran agama Hindu banyak terdapat nilai-nilai susila yang dapat ditanamkan pada anak usia dini misalnya mengajarkan anak untuk tidak

menyiksa/membunuh/menyakiti (Ahimsa), setia akan janji yang menyebabkan senangnya orang lain (Satya), tidak mencuri/tidak curang (Asteya), tidak dikuasai oleh kemarahan (Akrodha), hormat, taat dan tekun melakukan ajaran-ajaran guru (Guru susrusa), cinta kasih sayang terhadap sesama makhluk (Priti), bersikap ramah tamah, lemah lembut, sopan santun (Madhurya), bersikap rendah hati (Mardawa), memberikan sedekah (Dana), melakukan pemujaan terhadap Sang Hyang Widhi dan leluhur (Ijya), tekun 
memusatkan pikiran terhadap Sang Hyang Widhi (Dhyana), melakukan pensucian diri setiap hari dengan jalan membersihkan badan dan bersembahyang (Snana) (Sudharta dan Atmaja, 2001:52-55).

Penanaman nilai agama Hindu pada anak usia dini tersebut tidak bisa dilakukan dengan cara guru hanya memberikan teori dan pemahaman saja tetapi pembelajaran yang seharusnya diterapkan pada anak usia dini adalah pembelajaran yang menyenangkan. Pembelajaran yang menyenangkan dapat dikemas dengan cara mengajak anak-anak untuk bermain sambil belajar atau mengajak anak-anak untuk bermain peran dan mempraktekkan langsung nilai-nilai agama Hindu tersebut. Pembelajaran ini dilakukan karena pada masa anak usia dini terjadi pematangan fungsifungsi dan psikis yang siap merespon stimulasi yang diberikan oleh lingkungan sehingga pada masa ini merupakan tempo untuk meletakkan dasar pertama dalam mengembangkan sosial emosional, disiplin diri, nilai-nilai agama, konsep diri dan kemandirian (Wiguna, 2021).

Idealnya pola pembelajaran adalah ketika pembelajaran mampu menumbuhkan keseimbangan daya intelek (IQ), kecerdasan fisik (PQ), kecerdasan emosi (EQ) dan kecerdasan spiritual (SQ).

Namun dewasa ini pembelajaran hanya menekankan pada peningkatan daya intelek (IQ), sehingga berimplikasi pada keringnya rohani dalam diri manusia. Kekeringan ini yang menyebabkan manusia semakin jauh dari karakter manusia yang sesungguhnya, akibatnya lahirlah manusia-manusia yang cerdas secara jasmani namun kering secara rohani dan spiritual. Kekeringan akan sentuhan rohani akan mengakibatkan jiwa seseorang kosong. Dalam dunia pendidikan, kekeringan sisi rohani akan berdampak buruk pada pembentukan karakter manusia. Manusia cenderung tumbuh menjadi manusia yang cerdas secara akal namun miskin secara spiritual. Banyak orang pintar, namun sedikit yang berkarakter (Wiguna, 2020).

$$
\text { Sama halnya dengan }
$$
pembelajaran yang diterapkan di TK Pelangi Dharma Nusantara, Denpasar Selatan. Di TK Pelangi Dharma Nusantara ini setiap harinya guru hanya menerapkan pembelajaran yang arah sasarannya hanya berfokus kepada ranah kognitif dan peningkatan daya intelek (IQ) saja, jadi anak-anak setiap harinya diberikan pengetahuan membaca, menulis dan berhitung. Hal tersebut juga disampaikan oleh anak-anak ketika peneliti melakukan city tour ke TK Pelangi Dharma Nusantara, Denpasar Selatan.

Berdasarkan data dan fakta yang ditemukan pada saat city tour ini maka peneliti mengambil kesimpulan bahwa penanaman nilai agama Hindu ini penting dan perlu untuk diteliti, 
karena apabila hanya pengetahuan membaca, menulis dan berhitung setiap harinya diterapkan lalu kapan penanaman nilai agama Hindu tersebut bisa masuk dan diajarkan kepada anak-anak. Sementara penanaman nilai agama Hindu ini sangat penting terutama ditanamkan pada anak usia dini agar nantinya dapat membentuk anak yang bermoral dan berkarakter. Penanaman nilai agama Hindu ini juga akan berdampak pada perkembangan anak di usia SD, SMP, SMA hingga di masa depannya. Berdasarkan uraian latar belakang masalah yang telah dikemukakan di atas, peneliti tertarik untuk melakukan penelitian di TK Pelangi Dharma Nusantara, Denpasar Selatan. TK yang berdiri di bawah naungan Yayasan Pelangi Dharma Negara ini juga banyak merekrut guru atau tenaga pendidik yang berasal dari guru non PGTK/PGPAUD, keadaan ini yang membuat guru lebih menerapkan pembelajaran yang berfokus kearah kognitif dan kurang menanamkan nilai agama Hindu pada anak. Berdasarkan keadaan tersebut maka peneliti tertarik untuk meneliti bagaimana Penanaman Nilai Agama Hindu pada Anak Usia Dini di TK Pelangi Dharma Nusantara, Denpasar Selatan.

\section{METODE}

Penelitian ini dirancang untuk membahas mengenai penanaman nilai agama Hindu pada anak usia dini di
TK Pelangi Dharma Nusantara, Denpasar Selatan. Dalam penelitian ini menggunakan rancangan kualitatif dengan pendekatan interpretative. Pendekatan interpretative digunakan karena hasil penelitian lebih berkenaan dengan interpretasi terhadap data yang ditemukan di lapangan. Adapun jenis data yang digunakan dalam penelitian ini adalah data Kualitatif mengenai penanaman nilai agama Hindu pada anak usia dini di TK Pelangi Dharma Nusanatara, Denpasar Selatan. Data primer dalam penelitian ini diperoleh dari pengamatan dan wawancara dengan orang atau pihak-pihak yang dianggap mengetahui atau berperan dalam bidang pendidikan seperti kepala sekolah, guru wali kelas, pegawai TU, orang tua siswa dan beberapa siswa TK A dan TK B yang ada di TK Pelangi Dharma Nusantara Denpasar. Data sekunder ini merupakan data yang diperoleh secara tidak langsung dari TK Pelangi Dharma Nusantara akan tetapi diperoleh dari data lain seperti buku-buku penunjang penelitian lainnya. Teknik Pengumpulan Data menggunakan metode observasi, wawancara dan studi dokumen.

\section{PEMBAHASAN}

\subsection{Metode Penanaman Nilai Agama}

Hindu pada Anak Usia Dini di TK Pelangi Dharma Nusantara

Dalam menanamkan nilai agama Hindu pada anak usia dini di TK Pelangi Dharma Nusantara, metode 
merupakan komponen terpenting dalam penanaman ini. Tanpa adanya metode suatu materi pendidikan tidak berjalan sempurna. Hal ini disebabkan karena metode sangat berpengaruh terhadap keberhasilan proses penanaman nilai, disamping itu metode juga merupakan jalan bagi guru untuk menyampaikan materi yang ada. Adapun metode yang digunakan di TK Pelangi Dharma Nusantara ini adalah metode bermain, metode pembiasaan, metode karya wisata dan metode keteladanan.

\section{Metode Bermain}

Dengan bermain, seorang anak sesungguhnya sedang mengembangkan daya pikir, memperluas keingintahuan dan menyibukkan seluruh panca indranya. Seperti yang dikatakan oleh Miss.Maya selaku Kepala TK Pelangi Dharma Nusantara.

"Metode bermain adalah metode pengajaran yang dilakukan melalui permainan yang dapat memotivasi siswa dalam sebuah proses pembelajaran. Untuk membuat anak termotivasi dalam kegiatan main, kita disini memadukan rasa senang anak dengan dukungan dari sentrasentra yang diadopsi dari metode BCCT seperti sentra persiapan, sentra peran, sentra balok, sentra alam dan sentra otmus".

Penuturan yang disampaikan oleh Miss.Maya tersebut juga hampir sama denga penuturan yang disampaikan oleh guru-guru TK Pelangi Dharma Nusantara.

"Metode bermain yang kami terapkan disini mengadopsi dari metode BCCT gek. Jadi dengan metode ini kita lebih jelas untuk melakukan pengamatan kepada anak-anak. Karena metode BCCT ini merupakan metode bermain yang terbagi dengan beberapa sentra yaitu sentra persiapan, sentra peran, sentra balok, sentra alam dan sentra otmus".

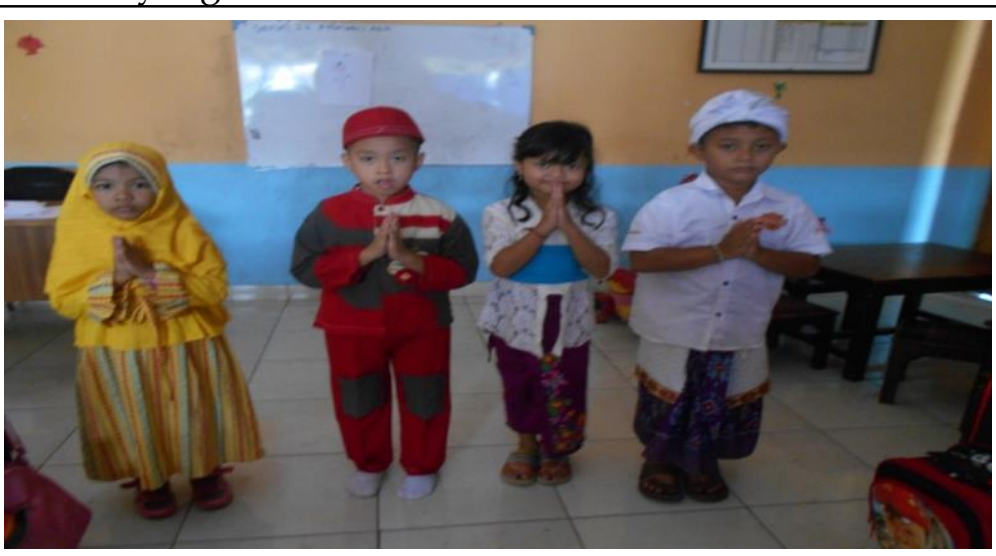

Gambar 1. Siswa TK Pelangi Dharma Nusantara mengikuti proses belajar mengajar melalui kegiatan bermain peran dengan tema Agama di Indonesia dan mengenakan pakaian adat Hindu dan Islam. 
2. Metode Pembiasaan

Pembiasaan merupakan salah satu metode pengajaran yang dilakukan secara berulang-ulang agar dengan cara tersebut dapat menjadi suatu kebiasaan.

Seperti yang dikatakan oleh Miss.Maya selaku Kepala TK Pelangi Dharma Nusantara.

$\begin{array}{lrr}\text { "Kalau dengan } & \text { metode } \\ \text { pembiasaan, } & \text { kita } & \text { biasanya } \\ \text { melatih } & \text { anak } & \text { untuk }\end{array}$ menghormati orang yang lebih tua dari mereka, selalu kita ajak salaman. Mengambil sesuatu dengan menggunakan tangan kanan, berdoa sebelum dan sesudah kegiatan, melaksanakan sembahyang bersama pada saat hari Purnama. Tetapi hanya saja disini pada saat anak-anak melakukan persembahyangan masih banyak yang terkadang bermain-main dan anak-anak belum bisa mengikuti doa Gayatri Mantra yang diucapkan missnya. Padahal saya sebagai kepala sekolah sudah berulang kali menegur miss-missnya agar ucapan doa minimal doa Gayatri Mantra itu diajarkan kepada anaanak"

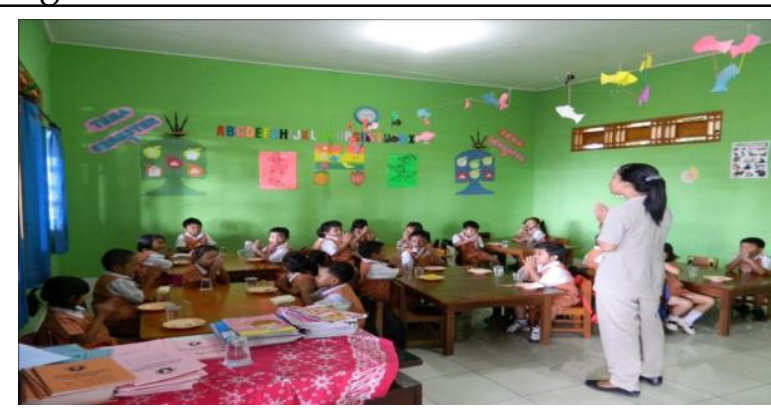

Gambar 2: Siswa TK Pelangi Dharma Nusantara berdoa sebelum dan sesudah kegiatan

3. Metode Karya Wisata

Metode karya wisata merupakan metode yang dalam pelaksanaannya dilakukan dengan cara mengamati secara langsung objekobjek tertentu sebagai pengayaan pengajaran dan pemberian pengalaman belajar yang tidak mungkin diperoleh anak di dalam kelas.

Seperti yang diungkapkan oleh Miss. Made selaku guru di TK Pelangi Dharma Nusantara.

"Kalau dengan metode ini kita biasa menerapkannya saat ada kegiatan jeda atau saat tamasya gek. Yang tahun ajaran ini kita jeda ke museum Bali dan sembahyang ke pura jagatnata, terus juga beberapa dari anak-anak ikut kunjungan ke panti jompo, tahun kemarinnya kita tamasya ke The Sila's Agrowisata dan tahun ini kita akan bertamasya ke Bali Safari Marine Park. Dengan metode ini anak-anak dapat melihat secara langsung berbagai ciptaan Tuhan dan diharapkan dapat dijaga dan dirawat secara langsung oleh anak untuk menambah wawasan dan pengetahuannya" (Miss. Made wawancara 3 Mei 2016). 


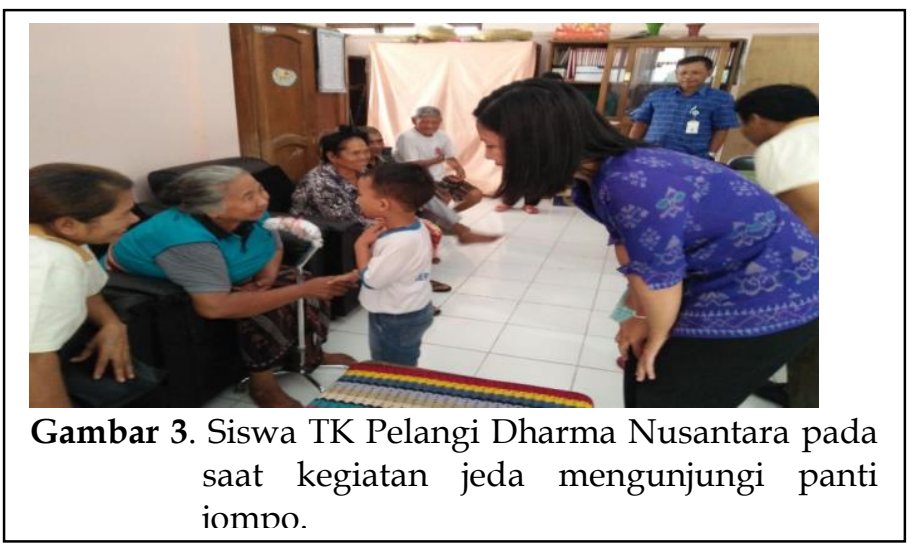

4. Metode Keteladanan

Metode keteladanan merupakan metode yang dilakukan dengan memperlihatkan contoh yang baik kepada siswa. Seperti yang diungkapkan oleh Miss. Maya selaku Kepala Sekolah TK Pelangi Dharma Nusantara.

"Yang diterapkan disini sebenarnya apabila ada peserta didik yang berantem sampai pukul-pukulan kita memisahkan bukan mengatakan jangan melainkan dengan sayangi teman karena kalau kita bilang jangan nanti kita membatasi mereka. Soalnya umur segitu kan mereka ingin taunya besar sekali gek. Dalam hal ini saya juga sudah wanti-wanti mengarahkan miss-missnya disini, tapi terkadang ada saja yang masih tidak menghiraukan, terkadang ada beberapa missnya yang salah cara menegur anakanak dengan berteriak-teriak jadinya anak-anak kalo ngomong jadi ikut-ikutan seperti itu. Saya juga jadi serba susah gek". 


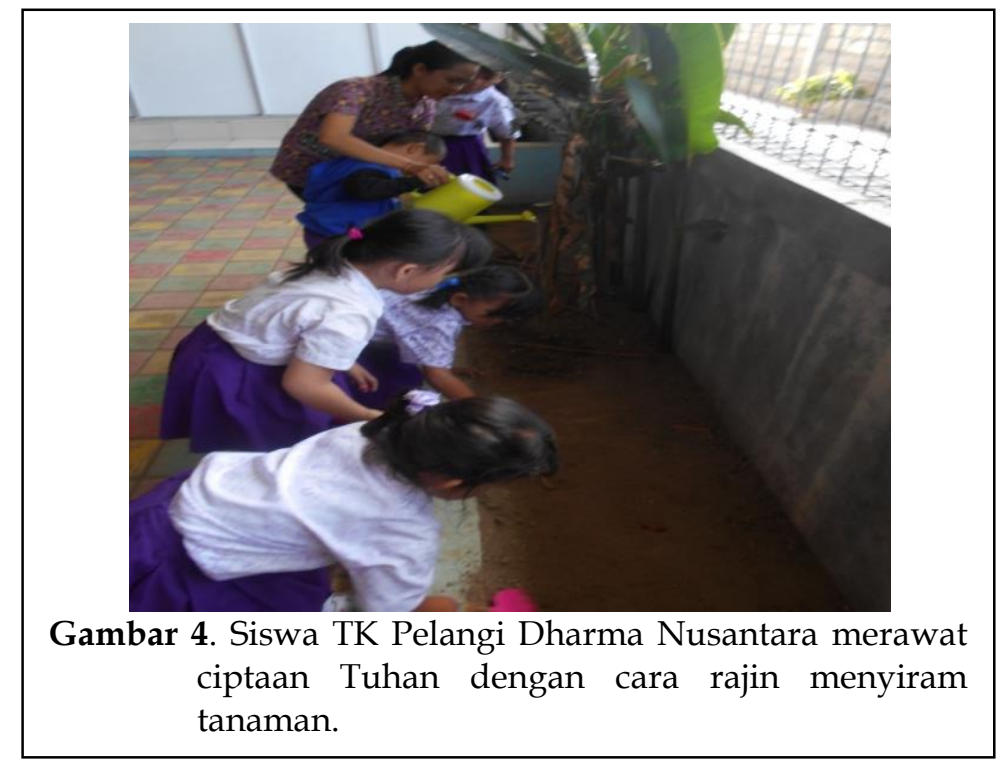

Dari hasil wawancara di atas,

dapat disimpulkan bahwa apa pun metode yang digunakan dalam menanaman nilai agama Hindu pada anak usia dini di TK Pelangi Dharma Nusantara adalah untuk memudahkan guru dalam prosesnya menanamkan nilai agama tersebut pada siswa. Hanya aja didalam menerapkan metode tersebut guru harus benar-benar memahami metode yang akan diterapkan sehingga apa yang ditanamkan kepada siswa dapat diterima dan dipahami oleh siswa dengan baik dan benar. Penerapan metode yang benar akan berdampak terbentuknya sikap dan karakter yang baik pula pada siswa.

Dalam kitab Mānava Dharmaśāstra bab II pasal 175 disebutkan bahwa:

"sevete māmstu niyamān brahmacārì gurau vasam, sañniyamyendriya grāmam tapo vrddhyartham àtmanah"

\section{Terjemahannya:}

Adapun seorang siswa yang tinggal bersama gurunya harus mengikuti peraturan serta larangan sebagai dibawah ini, untuk mengendalikan seluruh pañca indranya guna menambah kemampuan spiritualnya. (Pudja, 2004)

\section{2 Upaya Guru dalam Mengatasi Problematika Penanaman Nilai Agama Hindu pada Anak Usia Dini di TK Pelangi Dharma Nusantara \\ Dalam suatu hambatan yang} ditemui pasti ada suatu upaya yang dilakukan untuk mengatasi hambatan tersebut. Adapun upaya-upaya yang dilakukan guru dalam mengatasi problematika penanaman nilai agama Hindu pada anak usia dini di TK Pelangi Dharma Nusantara ini seperti yang diungkapkan oleh Miss.Maya 
selaku Kepala TK Pelangi Dharma Nusantara.

"Kita sebagai seorang pendidik terutama dalam mendidik anak-anak di usia dini ini tentunya ada beberapa hal yang menjadi kendala bagi kami dalam menanamkan nilai agama Hindu pada anak diantaranya adalah tidak semua anak-anak memiliki sifat yang mudah diberikan arahan, ada anak yang cuek, aktif bahkan hiperaktif di sekolah ini. Selama ini upaya yang dilakukan guru dalam mengatasi kendala ini adalah berusaha terus memberikan pengawasan dan tidak hentinya memberikan pemahaman dan mengenalkan perilaku mulia kepada anak-anak selain itu juga guru harus memiliki pengalaman dan wawasan tentang nilai agama Hindu itu untuk dapat ditanamkan nantinya pada siswa. Namun banyak missnya disini yang kurang memahami hal itu sehingga masih perlu terus dibina dan diarahkan agar lebih kompeten".

Hal lain juga diungkapkan oleh Miss.Widi tentang kendala dan upaya yang dilakukan dalam menanamkan nilai agama Hindu.

"Pendidikan anak bukan hanya tanggung jawab sekolah. Rumah sebagai tempat tinggal anak juga akan mempengaruhi. Keluarga yang disiplin, sopan dan santun adalah contoh baik yang akan ditiru oleh anakanak. Sebaliknya keluarga broken home, kacau juga akan mempengaruhi kualitas pemahaman nilai-nilai agama dan moral anak. Sehingga kondisi dalam keluarga menjadi sangat berarti bagi peningkatan pemahaman agama anak. Maka dengan kendala tersebut sikap dan perilaku anak menjadi agak susah untuk diatur,kurang disiplin dan suka mencari perhatian yang berlebih di luar serta anak menjadi hiperaktif. Biasanya kami memberikan perhatian dan pemahaman serta pengawasan yang ekstra kepada anak tersebut atau juga melakukan konseling kepada orang tuanya dengan harapan anak itu dapat mengerti dan merubah sedikit demi sedikit sikapnya yang buruk".

Dari hasil wawancara di atas, dapat disimpulkan bahwa selama ini kendala yang dihadapi guru dalam menanamkan nilai agama Hindu di TK Pelangi Dharma Nusantara adalah sebagian besar bersumber dari siswa yang kurang fokus dan susah untuk diarahkan oleh karena itu guru berupaya untuk memberikan pemahaman dan perhatian kepada siswa dan terus berusaha mengarahkan siswa agar menjadi lebih baik. Selain itu kendala dari kurang pahamnya guru menerapkan metode dalam menanamkan nilai agama Hindu pada anak dapat diatasi dengan memberikan banyak pembinaan, tuntunan dan wawasan untuk guru sehingga proses belajar mengajar dapat berjalan sesuai dengan yang diharapkan. Dalam kitab Sārasamuccaya Sloka 166 disebutkan bahwa:

"yo lokāmanugrhnāti daridram dinamānasam,

sa putrapașubhiroraddhin yașașcākșayamașnute"

\section{Terjemahannya:}

Adalah orang yang perilakunya demikian: memberikan hadiah, dengan senang hati memberi pelajaran dan 
nasehat kepada orang miskin, senanglah hatinya; orang yang demikian keadaannya itu, berkembanglah/selamatlah anakanaknya, cucu-cucunya, semua keturunannya sampai kesemua ternaknya, dan lagi akan dikenallah perbuatannya dalam bidang kebajikan.

\subsection{Implikasi dari Penanaman Nilai} Agama Hindu terhadap Perkembangan Sikap dan Perilaku pada Anak Usia Dini di TK Pelangi Dharma Nusantara

Pengaruh baik dan buruk dalam perkembangan perilaku siswa tergantung dari cara, pengalaman dan perlakuan yang diterima anak didik dilingkungannya.

Dengan menanamkan nilai agama Hindu pada anak usia dini di TK Pelangi Dharma Nusantara diharapkan dapat berdampak baik dan positif bagi perkembangan sikap dan prilaku siswa. Seperti yang diungkapkan oleh Miss. Maya sebagai Kepala TKPelangi Dharma Nusantara.

"Saya disini bersama dengan missnya yang lain akan berusaha terus membimbing anak-anak, selama ini anak-anak yang kami didik sih dari awal masuk ke sekolah ini sampai sekarang sudah bisa dibilang ada perubahan sikap ya gek, selama hampir setahun ini mereka sudah bisa mandiri, mengucapkan salam, berdoa sebelum dan sesudah kegiatan, mengenal ciptaan Tuhan, saling membantu teman juga, ya walaupun tidak semua anak begitu tapi memang sebagian besar saya melihat sudah ada perubahan sikap semenjak belajar disini".

Hal tersebut juga disampaikan oleh Ms. Widi selaku guru di TK Pelangi Dharma Nusantara.

"Kalau dibilang soal dampaknya dari penanaman nilai agama yang kita ajarkan kepada anakanak sudah pasti ada dampaknya gek, misalnya dengan nilai-nilai agama yang kita tanamkan selama ini, anak-anak mengetahui perilaku yang baik/sopan dan buruk, sudah mengenal tentang agama yang dianutnya terus mengetahui hari besar agamanya terus juga sudah bisa menjaga kebersihan dirinya dan lingkungannya. Dari hal itu saja sudah memberikan dampak yang positif bagi anak". 


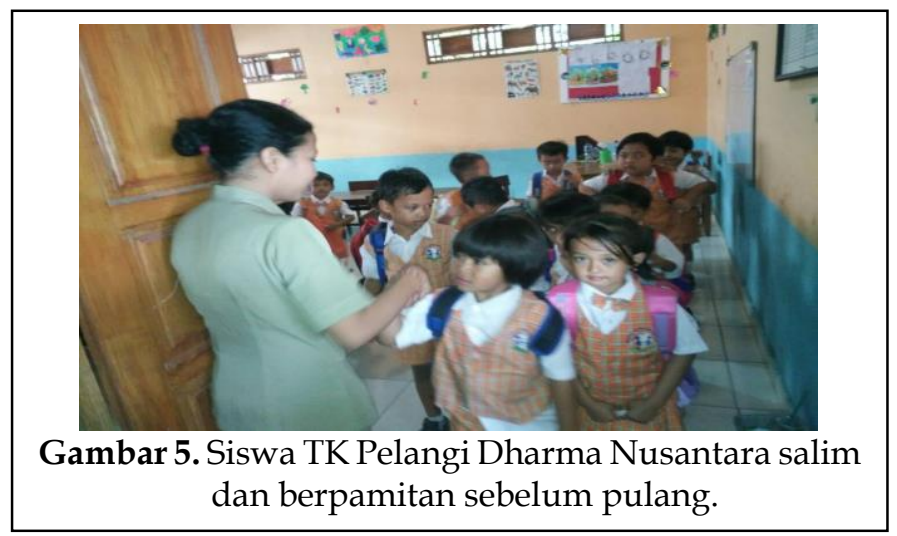

Dari hasil wawancara di atas, nilai agama Hindu pada anak usia dini dapat disimpulkan bahwa dampak di TK Pelangi Dharma Nusantara, yang muncul terhadap perkembangan maka dapat disimpulkan sebagai sikap dan perilaku siswa di TK Pelangi berikut:

Dharma Nusantara cukup memberikan hasil yang baik sehingga muncul perubahan sikap dan perilaku yang positif bagi siswa. Dengan tertanamnya nilai agama Hindu yang baik pada siswa, akan mampu memfilter pengaruh tidak baik dari luar sehingga siswadapat membedakan mana perbuatan yang baik dan tidak baik bagi dirinya. Dalam kitab Sārasamuccaya Sloka 241 disebutkan bahwa:

"pitā mātā ca rājendra tusyato yasya dehinah,

iha pretya ca tasyātha kirtirbhavati șāṣvatī"

Terjemahannya:

Setia bakti terhadap orang tua, membuat orang tua itu sangat senang dan puas hatinya, pahalanya baik sekarang ini; maupun kemudian, tetap mendapat pujian tentang kebajikan (Kadjeng, 1997).

\section{SIMPULAN}

Berdasarkan penelitian yang telah dilakukan mengenai penanaman

kegiatan penanaman nilai agama Hindu pada anak usia dini di TK Pelangi Dharma Nusantara meliputi empat metode yaitu metode bermain untuk mengembangkan daya pikir, memperluas keingintahuan dan menyibukkan seluruh panca indra anak, metode pembiasaan yang dilakukan secara berulang-ulang agar dapat menjadi kebiasaan yang baik bagi anak-anak, metode karyawisata yaitu metode yang dalam pelaksanaannya dilakukan dengan cara mengamati secara langsung keadaan sekitar atau daerah tujuan dan metode keteladanan yaitu metode yang dilakukan dengan memperlihatkan contoh yang baik kepada anak-anak.

Upaya yang dilakukan guru dalam mengatasi problematika penanaman nilai agama Hindu pada anak usia dini di TK Pelangi Dharma Nusantara adalah dengan berusaha terus mengadakan pengawasan, tidak hentinya memberikan pemahaman, 
mengenalkan perilaku mulia kepada anak-anak atau juga melakukan konseling kepada orang tua siswa dengan harapan anak tersebut dapat mengerti dan merubah sedikit demi sedikit sikapnya yang kurang baik. Selain itu juga akan diupayakan untuk memberikan pembinaan dan arahan kepada seluruh guru agar lebih memahami metode dalam menanamkan nilai agama Hindu pada anak.

Implikasi dari penanaman nilai agama Hindu terhadap perkembangan sikap dan perilaku pada anak usia dini di TK Pelangi Dharma Nusantara yaitu sebagian besar dari anak-anak sudah menunjukkan perubahan sikap dan perilaku yang lebih baik dari sebelumnya, seperti dari anak yang tidak bisa bangun pagi sudah bisa bangun pagi. Implikasi lainnya adalah memiliki sikap mandiri, dapat bersosialisasi dengan teman, menghormati guru dan orang tua, memberi salam dan berpamitan kepada guru dan orang tua, berdoa sebelum dan sesudah kegiatan serta bisa menjaga kebersihan diri dan lingkungan.

\section{DAFTAR PUSTAKA}

Asri, B. (2012). Belajar \& Pembelajaran. Rineka Cipta: Jakarta.

Depdiknas. 2014. Kamus Besar Bahasa Indonesia Edisi ke Empat. Jakarta: PT. Gramedia Pustaka.
G.Pudja dan Tjokorda Rai Sudharta. 2004. Mānava Dharmaśāstra atau Weda Smṛti Compendium Hukum Hindu. Surabaya: Paramita.

Isjoni, H. (2010). Model Pembelajaran Anak Usia Dini. Jakarta: Gunung Mulia.

Kadjeng, I Nyoman, dkk. 1997. Sārasamuccaya Dengan Teks Bahasa Sanskerta Dan Jawa Kuna. Surabaya: Paramita.

Fadlillah, M., \& Khorida, L. M. (2013). Pendidikan karakter anak usia dini. Jogjakarta: Ar-Ruzz Media, 25.

Sandika, I. K. (2014). Membentuk Siswa Berkarakter Mulia melalui Pola Pembelajaran Pendidikan Agama Hindu. Surabaya: Paramita.

Sardiman, A. M. (2007). Jakarta: Interaksi \& Motivasi Belajar Mengajar. Pt Raja Grafindo Persada.

Sudharta, T. R., \& Atmaja, I. B. O. P. (2001). Upadeśa tentang ajaranajaran agama Hindu. Pāramita.

Suyadi, S., \& Nur, N. (2017). Teori Pembelajaran Anak Usia Dini Dalam kajian Neurosains. PT Remaja Rosdakarya.

Undang-Undang Republik Indonesia No. 20, Tahun 2003 tentang Sistem Pendidikan Nasional. 2003. Jakarta: Permata Press.

Wiguna, I. B. A. A. (2020). POLA ASUH

DALAM

PENUMBUHKEMBANGAN

KARAKTER TOLERANSI ANAK 
USIA DINI DILINGKUNGAN

MINORITAS. Prosiding STHD

Klaten Jawa Tengah, 1(1), 119129.

Wiguna, I. B. A. A. (2021, March).

Kepemimpinan Kepala Sekolah
PAUD Di Masa Pandemi Covid19. In Prosiding Seminar Nasional Institut Agama Hindu Negeri Tampung Penyang Palangka Raya (No. 1, pp. 221233). 